\title{
The Development of Preservice Elementary Teachers' Curricular Role Identity for Science Teaching
}

\author{
CORY T. FORBES, ELIZABETH A. DAVIS \\ Department of Educational Studies, School of Education, University of Michigan, \\ Ann Arbor, MI 48109-1259, USA
}

Received 16 August 2007; revised 28 November 2007, 18 December 2007; accepted 20 December 2007

DOI 10.1002/sce.20265

Published online 19 February 2008 in Wiley InterScience (www.interscience.wiley.com).

\begin{abstract}
Curriculum materials are a crucial tool with which teachers engage in teaching practice. For preservice teachers to learn to use science curriculum materials in productive ways, they must develop a conception of themselves as elementary teachers in which the use of science curriculum materials is a valued dimension of science-teaching practice. We define those dimensions of teachers' professional role identities concerned with the use of curriculum materials as curricular role identity. This mixed-methods study examines preservice elementary teachers' development of curricular role identity for science teaching through their use of science curriculum materials. Forty-seven preservice elementary teachers in two sections of an elementary science methods course were studied over the course of one semester. Data sources include survey results from preservice teachers in both
\end{abstract}

An earlier version of this paper was presented at the Association for Science Teacher Education annual meeting in Clearwater Beach, FL, in January 2007.

Correspondence to: Cory T. Forbes; e-mail: ctforbes@umich.edu

Contract grant sponsor: National Science Foundation's PECASE./CAREER Award.

Contract grant number: REC-0092610.

Contract grant sponsor: Center for Curriculum Materials in Science, a Centers for Learning and Teaching (CLT) grant from the National Science Foundation.

Contract grant number: 0227557.

Any opinions, findings, and conclusions or recommendations expressed in this material are those of the authors. 
course sections as well as interviews, observations, and course artifacts from preservice teachers studied in-depth. Results suggest preservice teachers articulate important differences between their own and more experienced elementary teachers' curricular role identity for science teaching and make progress toward appropriating the latter. Supporting them to do so requires emphasizing interactions with science curriculum materials as part of teacher education and providing classroom-based experiences through which they can put their developing curricular role identities into action. $\quad$ (C) 2008 Wiley Periodicals, Inc. Sci Ed 92:909-940, 2008

\section{INTRODUCTION}

While systemic reform of science teaching is a daunting challenge, the current emphasis of science education reform on standards-based, inquiry-oriented teaching (American Association for the Advancement of Science [AAAS], 1993; National Research Council [NRC], 1996) has been advanced in a range of contexts and through a variety of methods, including preservice teacher education, professional development, and the development of science curriculum materials. Of these various means of translating science education reform in classroom practice, however, it is arguably curriculum materials that can have the greatest effect on day-to-day teaching and learning (Brown \& Edelson, 2003). As Shulman (1986) noted more than 20 years ago, these materials represent the "pharmacopia for teaching" and act as an essential tool with which teachers craft teaching practice. The term "science curriculum materials" can be defined broadly as including both the physical tools used in science classrooms (such as laboratory apparati, instruments, and technology) and the representational tools (such as text-based artifacts and graphics) around which the use of physical tools is structured (Brown, 2002). Consistent with recent research on teachers and curriculum materials (Davis \& Krajcik, 2005; Remillard, 2005), we focus on curriculum materials as representational tools.

The relationship between teachers and curriculum materials is characterized by a process of curriculum design. Teachers evaluate, adapt, and enact curriculum materials in light of their own unique needs, those of their students, and the contexts in which they work. Through iterative cycles of curriculum design, teachers can learn to engage with curriculum materials and in teaching practice more productively. In light of recent research on teachers' use of curriculum materials, Remillard (2005) has proposed a model of the teacher-curriculum relationship that captures this curriculum design process, emphasizing the importance of a participatory relationship between teachers and curriculum materials, how this relationship plays out in particular contexts, and opportunities for teacher learning that emerge from engaging in curriculum design.

Teachers' ability to engage in curriculum design at a classroom level, or pedagogical design capacity (Brown, 2002, in press), is a function not only of context but also the nature of the curriculum materials themselves and individual teacher characteristics, including their knowledge and beliefs (Remillard \& Bryans, 2004; Roehrig \& Kruse, 2005; Schneider, Krajcik, \& Blumenfeld, 2005). However, the influence of teachers' knowledge and beliefs on their use of curriculum materials may not tell the whole story (Brown, 2002; Enyedy, Goldberg, \& Welsh, 2006). Teachers' knowledge and beliefs contribute more generally to their orientations toward teaching practice, including the use of curriculum materials (Remillard \& Bryans, 2004). These orientations can be defined as a set of perspectives and dispositions toward curriculum materials and salient, curriculum materials-specific dimensions of teaching practice in which identity is foregrounded. We define curricular role identity, then, as those dimensions of an individual's professional teaching identity that are concerned with the use of curriculum materials and suggest this construct is a useful 
tool to better understand preservice and in-service teachers' use of science curriculum materials.

Given the calls for research on the relationship between teacher characteristics, including identity, and teachers' use of curriculum materials (Remillard, 2005), we undertook research aimed at better understanding how preservice elementary teachers construct a teaching identity as they learn to use science curriculum materials. Specifically, we asked,

1. How do preservice elementary teachers conceptualize their role identity in respect to curriculum materials?

2. How do preservice elementary teachers' curricular role identities develop through their use of science curriculum materials at this early stage along the teacher professional continuum?

While a substantial amount of research has focused on in-service teachers' use of science and mathematics curriculum materials (Collopy, 2003; Enyedy \& Goldberg, 2004; Fishman, Marx, Best, \& Tal, 2003; Lloyd, 1999; Pintó, 2004; Remillard, 1999; Remillard \& Bryans, 2004; Roehrig \& Kruse, 2005; Schneider et al., 2005), only recently has research begun to explore preservice elementary teachers' use of and learning from science curriculum materials (Davis, 2006; Dietz \& Davis, in press; Schwarz et al., in press). The results presented here extend this research by examining preservice elementary teachers' relationships with science curriculum materials through the lens of identity.

\section{THEORETICAL FRAMEWORK}

Identity, particularly role identity, has served as an important construct in research on teachers and teaching (Bullough, Knowles, \& Crow, 1992; Enyedy et al., 2006; Mahlios, 2002; Smithey \& Davis, 2004). In articulating a perspective on curricular role identity, we first explore theoretical perspectives on identity and role identity and then discuss implications for preservice teachers' identity development.

\section{Identity and Role Identity}

Identity can be thought of as an all-encompassing representation of "a person's evaluative stance toward interaction. . cast in the romantic folk language of "who we are" (Lemke, 2000 , p. 283). In this way, identities exist as reifications and within relevant social practices. For teachers, identity is a function of their knowledge, beliefs, self-efficacy, and general dispositions toward teaching practice and the evolution of these characteristics over time through classroom practice (Collopy, 2003; Drake, Spillane, \& Hufferd-Ackles, 2001). Thus, a teacher's identity is fundamentally intertwined with knowing and social membership (Lave \& Wenger, 1991).

As representations, identities are multidimensional in that they originate and develop across contexts and time. Gee (2000-2001) describes four ways to view identity: as nature based, institutionally based, discursive, and affinity based. Identities fashioned around particular roles, or role identities, are the result of individuals' classification of themselves in relation to existing socially meaningful categories (Stets \& Burke, 2000). Discussions of teachers' role identities are concerned, then, with how teachers fashion a sense of self around the role of teacher (Bullough et al., 1992). Teachers' role identities are particularly powerful because the role of teacher, consistent with Gee's (2000-2001) description, is institutionally sanctioned, defined by unique patterns of discourse, and reinforced by shared experiences between teachers. 
Just as participation in inquiry-oriented science can contribute to the development of students' identities (Lemke, 2001; Reveles, Kelly, \& Durán, 2007), teachers' identities also exist in and are developed through classroom practice (Enyedy et al., 2006; Lemke, 2000; Sfard \& Prusak, 2005). Teaching, the essential activity that defines a teacher, is a complex practice involving many different constituent practices, including the use of curriculum materials. While role identities can be thought of as role-specific global selfconcepts, they are also differentiated in that various practices, and the meanings associated with those practices, constitute any particular role (Collier, 2001). As such, teachers' identities can be broadly or narrowly defined, what Collier distinguishes between as the "panoramic" and "zoom-lens" views of role identity formation. Here, we focus on those aspects of preservice elementary teachers' role identities specifically related to their use of curriculum materials for elementary science teaching. As one of many dimensions that constitute preservice elementary teachers' role identities for science teaching, the notion of curricular role identity represents a more delineated or "zoom-lens" perspective on role identity.

In constructing an identity, an individual is shaped by and in turn shapes the practices of a community (Wenger, 1998). Teachers' role identity development relies on the ways in which a teacher envisions him- or herself fulfilling the role of teacher through practice. These hypothetical visions of what type of teacher an individual hopes to become are referred to as role standards or designated identities (Burke \& Reitzes, 1981; Collier, 2001; Sfard \& Prusak, 2005). However, certain individuals have a disproportionately significant influence on role identity development. Sfard and Prusak (2005) refer to influential individuals as "significant narrators" who, in the case of preservice and beginning teachers, are often practicing teachers whose practices they seek to appropriate through socialization to professional teaching (Zeichner \& Gore, 1990).

Individuals do not merely identify with and appropriate existing role identities but also actively negotiate their meaning. The ways in which individual teachers participate in a particular community reflect their perspectives on the norms and practices of the community itself (Graue, 2005; Holland, Lachicotte, Skinner, \& Cain, 1998; Kozoll \& Osborne, 2003). However, as more peripheral participants in the teaching profession, preservice and beginning teachers are less well positioned to actively affect change in their teaching contexts. As such, novice teachers' role identity development is more heavily characterized by role appropriation than role negotiation.

\section{Preservice Elementary Teachers' Development of Curricular Role Identity}

Just as teachers orient their role identity development in light of role standards or designated identities, for preservice teachers, classrooms can be thought of as figured worlds for which they are being prepared (Boaler \& Greeno, 2000; Graue, 2005; Kozoll \& Osborne, 2003). The frameworks they construct for role identity formation within these figured worlds are most heavily influenced by their experiences in three domains: their own history as students, the nature of the teacher education program, and their limited classroom experiences (Mahlios, 2002). Owing to preservice teachers' limited experience in the role of teacher, their ideas about teaching are largely based on their own past experiences as students (Lortie, 1975). At the preservice stage of the professional continuum, identity development is heavily influenced by these powerful notions of self that, even for in-service science teachers, are often deeply personal (Helms, 1998).

The salience of these entrenched ideas about teaching has provided fodder for criticisms of formal teacher education (Richardson, 1996; Zeichner \& Conklin, 2005; Zeichner \& 
Gore, 1990). Nonetheless, just as teacher education experiences can support preservice teachers to negotiate these ideas and learn to teach inquiry-oriented science (Crawford, 1999; Windschitl, 2003), so too can they support preservice teachers' learning to critique and adapt science curriculum materials (Davis, 2006). To put these abilities to use and develop robust pedagogical design capacity (Brown, 2002, in press), preservice teachers must develop a teaching identity in which the active use of science curriculum materials is valued and perceived as role appropriate. We define this aspect of their professional identity as a teacher as curricular role identity and explicitly seek to support its development through formal teacher education.

Through our work as elementary science teacher educators and science curriculum developers, we have investigated how preservice elementary teachers use and learn from science curriculum materials (Davis, 2006; Dietz \& Davis, in press; Forbes \& Davis, in press). We have found Remillard's (2005) model of the teacher-curriculum relationship useful. This framework has largely been developed within the context of mathematics education, and we acknowledge inherent differences between the fields of mathematics and science education. The goals and design of mathematics curricula, for example, are domainspecific and, therefore, necessarily distinct from those of science education. In addition, while mathematics education has enjoyed a prioritization in recent years in the elementary grades, science as a subject has not (e.g., Marx \& Harris, 2006), thereby fundamentally impacting the curricular contexts in which elementary teachers use both mathematics and science curriculum materials.

However, for elementary teachers, essential elements of the Remillard (2005) modelthe teacher, the curriculum materials, and the ways in which interactions between the two in particular contexts are instantiated in changes to the curriculum materials and teachers' knowledge, beliefs, and identities - are retained. For example, science curriculum materials, though different from mathematics curriculum materials, also possess particular features that make them more or less effective in representing domain-specific concepts and practices to both teachers and students (Beyer, Delgado, Davis, \& Krajcik, submitted for publication; Kesidou \& Roseman, 2002). The generalizability of Remillard's model provides a framework through which to articulate the ways in which these differences play out in teachers' use of curriculum materials.

We apply Remillard's (2005) model to elementary science teacher education. Preservice teachers, working in methods courses and placement classrooms, engage in heavily scaffolded learning experiences that are, in many cases, different from those of that practicing teachers experience on a day-to-day basis. For example, Remillard's model assumes repeated cycles of curriculum design with the same curriculum materials, an opportunity that preservice teachers are rarely afforded. However, it is still helpful in capturing specific instances of curriculum design. Even if preservice teachers do not further refine and enact the same curriculum materials, experiences modifying, adapting, and enacting unique curriculum materials over time retain their iterative nature in that they afford preservice teachers opportunities to develop requisite knowledge, beliefs, and identity through curriculum design. Indeed, these types of teacher education experiences may be more authentic than we often assume. In-service elementary teachers sometimes find themselves in situations where they are not afforded opportunities to plan for and enact the same science lessons repeatedly over time (Forbes \& Davis, submitted for publication). By drawing upon this framework, we seek to explore how curricular role identity influences preservice teachers' use of science curriculum materials and further illuminates the field's understanding of preservice elementary teachers' unique needs and learning at this stage of the teacher professional continuum (Feiman-Nemser, 2001). 


\section{METHODS}

This complementary mixed-methods study involved 47 preservice elementary teachers in two sections of an undergraduate elementary science teaching methods course. A survey instrument, developed by the authors to measure preservice teachers' developing curricular role identity for science teaching, was administered to preservice teachers in both sections of the course at the beginning and end of the term. From this whole group, eight preservice teachers were chosen to be studied qualitatively over the course of the semester in an effort to better understand how they constructed a curricular role identity for science teaching. These focus teachers also allowed us to illuminate trends in the survey data.

\section{Participants and Context}

This study took place during the third semester of an undergraduate elementary teacher preparation program at a large, midwestern university in the United States. The four-term, cohort-based program leads to a BA degree in education as well as recommendation for elementary teaching certification in the state. It is designed to promote the development of preservice teachers' pedagogical, subject-matter, and pedagogical content knowledge, and is aligned with foundational tenets of teacher education reform and standards documents (e.g., AAAS, 1993; NRC, 1996). During each of the first three semesters of the program, students undertake relevant university coursework and spend at least 6 hours per week in elementary classrooms under the tutelage of an experienced mentor teacher. The final term is centered around a traditionally structured, full-time, 14-15-week student-teaching experience.

During the third semester, the preservice teachers are enrolled in the elementary science teaching methods course, in which this study took place. There were two sections of the course, each taught by one of the authors. The elementary science teaching methods course is organized around three explicit goals. First, the course aims to help preservice elementary teachers develop an understanding of scientific inquiry and inquiry-oriented science teaching, including three essential features: questioning and predicting, explaining using evidence, and communicating and justifying findings (adapted from NRC, 2000). Second, preservice teachers learn to anticipate and address students' ideas, including their prior knowledge and alternative (nonscientific) ideas. Third, the course supports preservice teachers' learning to use science curriculum materials and development of pedagogical design capacity by affording them opportunities to critique, adapt, and enact science curriculum materials. The preservice teachers in the elementary science methods course studied here were representative of the population of elementary teachers in the United States in that most were women and most were Caucasian (National Center for Education Statistics [NCES], 2003). All were traditional fourth-year seniors (about 21 years old) in their final year of college.

\section{Data Sources and Collection}

The data reported here are both quantitative and qualitative, all collected over the course of the term in which the elementary science teaching methods course was taught. At the beginning of the term, preservice teachers from both sections of the course were asked to participate in the study. Of the 53 preservice teachers in the two sections, 47 consented to later analysis of their survey responses and coursework. In addition, 11 of these 47 students were invited to participate in the study subsample that involved a commitment to two interviews as well as observations of enacted science lessons. We chose these 11 preservice 
teachers by employing maximum variation sampling (Patton, 2001), the goal of which was to maximize variation across characteristics of interest. Given the similar experiences the preservice teachers were expected to have in the methods course itself, we attempted to garner participation from preservice teachers who varied in their field placement schools and the types of science curriculum materials with which they would work. Variation was also sought for gender and ethnicity to the extent possible within a population of preservice teachers that is usually quite homogeneous (NCES, 2003).

Of the initial 11 initially asked, 9 preservice teachers agreed to participate. Owing to logistical constraints, incomplete data were collected for one preservice teacher so the data reported here are drawn from eight preservice teachers. Of the eight preservice teachers, six were Caucasian females, one was an African-American female, and one was a Caucasian male. Each of these eight preservice teachers was placed in a different elementary classroom across seven different schools within four area school districts. We observed three different commercially available or district-created science curriculum materials being used (by six preservice teachers), as well as teacher-created science lesson plans (by two preservice teachers). The preservice teachers were reassured that they could withdraw their consent for participation at any time, though none of them opted to do so.

A survey instrument was developed to assess preservice elementary teachers' conceptions of the teacher's role in respect to curriculum and curriculum materials. The primary purpose of the survey was to obtain a gross measure of role identification that illuminated preservice teachers' conceptions of their own curricular role identities and those they attributed to experienced elementary teachers, a comparison of the two, and any changes that occurred in them over the course of the semester. The survey instrument, with individual survey items listed according to dimensions measured, is included in Appendix A.

However, because role identities are differentiated, we also sought to provide evidence for particular constituent dimensions of teachers' curricular role identities. On the basis of the Remillard's (2005) model of the teacher-curriculum relationship, we identified four dimensions of teachers' curricular role identity for science teaching. First, Remillard posits that teachers possess orientations toward the active, participatory use of curriculum materials in which they interpret, evaluate, and adapt curriculum materials (Dimension 1). This dimension of curricular role identity represents an overall perspective on the active use of curriculum materials. Second, teachers may engage in these curriculum design activities specifically to promote inquiry-oriented practices in the classroom (Dimension 2). Doing so involves accounting for students' existing ideas and promoting the use of scientifically oriented questions; gathering, organizing, and interpreting data; and constructing evidence-based explanations. Third, teachers account for context in their interactions with, planning for, and enactment of curriculum, including standards, benchmarks, and districtlevel curricular objectives, their perceived needs of their students, and the resources they have available (Dimension 3). Finally, fourth, teachers possess orientations toward their own capacity to learn directly from, and from the use of, curriculum materials, including pedagogical content knowledge and subject-matter knowledge (Dimension 4).

The survey instrument went through a number of iterative cycles of expert review, and this study represents its first pilot test. It was composed of 34 action statements. These action statements began with the generic phrase "Compared to all elementary teachers who teach science..." and for each statement the preservice teachers were asked to respond to this prompt in respect to a role standard ("effective science teachers") and self-descriptively ("I"). For example:

Compared to all elementary teachers who teach science...

-... effective science teachers are___to reflect on their use of curriculum materials in order to improve their practice. 
-... I am _-_to reflect on my use of curriculum materials in order to improve my practice.

A five-point Likert scale was employed $(5=$ much more likely; $1=$ much less likely) for scoring. For the aggregate results, we drew upon the entire set of survey items. The survey items were further subdivided into four sets of two corresponding questions organized around the four dimensions discussed previously (eight questions per dimension). These questions were used to generate data for each of the four dimensions of curricular role identity. In the results that follow, the scores for the preservice teachers' self-described role identity are referred to as "self" scores whereas the curricular role identity they attributed to more experienced elementary teachers is referred to as "role" scores.

In addition to survey data, eight preservice teachers were followed more closely over the course of the term. Two formal, semistructured interviews (Patton, 2001) were conducted with each of these preservice teachers, one at the beginning and one at the end of the course. The first interview was primarily focused on the preservice teachers' past experiences with and individual orientations toward science, science teaching, and science learning, as well as their ideas about curriculum materials for science. The second interview involved a discussion of a fictional teaching scenario, critique of a sample science lesson plan, reflection on their use of science curriculum materials in practice over the course of the term, and a more general discussion as to the nature of curriculum and curriculum materials and characteristics of effective instructional materials for science.

In the science methods course, the preservice teachers completed a number of reflective journal entries and course assignments, including critiques of existing science lesson plans, and participated in online discussions. Each preservice teacher's journal entries and online discussion entries, as well as a subset of course assignments, were used as data. In addition, they were required to develop and teach two science lessons in their placement classrooms over the course of the term. These assignments, called reflective teaching assignments, entailed identifying an existing science lesson, critiquing and modifying it for use in their instructional setting, enacting the lesson, and writing a follow-up reflective journal entry. Each of the eight preservice teachers was observed enacting one or two or their reflective teaching science lessons in their placement classroom and participated in a postenactment interview.

\section{Data Analysis}

The analysis of the survey and qualitative data involved a complementary mixed methods approach to allow us to characterize how preservice teachers conceptualize their roles as teachers in respect to curriculum materials, identify critical factors that mediate the development of curricular role identity, and illuminate the influence of curricular role identity and its development on fundamental elements of teacher learning and science teaching. The survey was designed to provide a measure of preservice teachers' conceptions of curricular role identity in respect to themselves ("I" or "self" survey items) and a role standard ("effective science teachers" or "role" survey items). The design allows us to compare the preservice teachers' responses to self and role survey items (16 each), as well as how they change over time.

To analyze the survey data, we first constructed frequency tables and obtained descriptive statistics. We then undertook reliability analysis of the survey as a whole and of results from the dimensions. To assess the survey instrument's effectiveness as an aggregate measure of curricular role identity for science teaching, we performed principal components analysis (PCA). The purpose of PCA is to identify fundamental factors in the data to which each individual survey item contributes. All paired survey items except for one loaded positively 
on one factor (see Appendix B), suggesting that the survey items were a coherent measure of one construct. This paired set of questions (\#33 and \#34) was dropped and excluded from the analysis. In addition, we found positive, significant correlations among all dimensions for both self and role scores, as shown in Appendix C, and a Cronbach's alpha reliability test of the entire survey yielded an $\alpha$ value of 0.91 . These analyses suggest that the survey instrument as a whole possesses high-internal reliability.

We also examined internal reliability of the four dimensions of curricular role identity measured. While not readily apparent through PCA, each of the constituent dimensions exhibited high internal reliability. Self and role survey items within each of the four dimensions were all positively correlated. Cronbach's alpha coefficients were 0.79 and 0.89 for self and role measures within Dimensions 1 and 2, respectively. For both Dimensions 3 and 4 , Cronbach's alpha coefficients were 0.71 . These analyses suggest that while the survey instrument possesses relatively high-internal reliability within each dimension measured, dimension-specific reliability was somewhat lower than for the survey as a whole and that within the four dimensions measured, internal reliability was somewhat higher for Dimensions 1 and 2 than for Dimensions 3 and 4. Furthermore, these coefficients also show that each of the survey questions contributed relatively equally to the overall variance: no single question or group of questions had a disproportionate effect on the aggregate or dimensional results. Results of reliability analysis from the survey data lend empirical support to the existing theoretical justification for the dimensionality of curricular role identity as a measurable construct.

After performing reliability analyses, paired-sample $t$-tests were undertaken to compare self and role scores from both pre- and postadministrations of the survey, as well as to compare changes in self and role scores over time. These statistics are reported in the results that follow. There were no statistically significant differences on any of the dimensions measured between the two sections of the course.

Qualitative analysis of additional data involved an iterative process of coding, reduction, displaying, and verification of data (Miles \& Huberman, 1994). The initial coding scheme was organized around the four categories of the teacher-curriculum relationship derived from the Remillard (2005) model. Within each of these categories, additional subcodes relevant to science teaching were employed to capture the teachers' talk about inquiryoriented teaching and learning. As analysis progressed, additional codes were added to account for emergent themes and, as definitive patterns emerged, the data were reduced to isolate and illustrate key factors. This process continued until dominant themes had been refined and substantiated. Our final coding key is presented in Table 1.

Pseudonyms are used for the preservice teachers in the results that follow.

\section{RESULTS}

\section{Overview of Results}

As a gross measure of the preservice teachers' curricular role identity development for science teaching over the course of the semester, we first present aggregate results from the survey. Statistics for self and role scores are presented in Table 2.

At the beginning of the semester, we observe a significant difference between the preservice teachers' curricular role identity and that which they attribute to more experienced elementary teachers. Over the course of the semester, both self and role scores increased, suggesting the preservice teachers constructed a curricular role identity for experienced elementary teachers that was based on an active and participatory relationship with curriculum materials and made strides in appropriating this vision for themselves. However, while the 


\section{TABLE 1 \\ Coding Key}

\begin{tabular}{|c|c|}
\hline Code & Description \\
\hline \multicolumn{2}{|c|}{ Development of curricular role identity } \\
\hline $\begin{array}{l}\text { Interactions with curriculum } \\
\text { materials toward crafting of } \\
\text { science learning environments }\end{array}$ & $\begin{array}{l}\text { References to interactions with and orientations } \\
\text { toward curriculum materials in practice }\end{array}$ \\
\hline $\begin{array}{l}\text { Interactions with curriculum } \\
\text { materials toward crafting of } \\
\text { science learning environments for } \\
\text { inquiry }\end{array}$ & $\begin{array}{l}\text { References to interactions with and orientations } \\
\text { toward curriculum materials in practice. Same as } \\
\text { "general" code but inquiry-specific }\end{array}$ \\
\hline $\begin{array}{l}\text { Influence of context on interactions } \\
\text { with curriculum materials }\end{array}$ & $\begin{array}{l}\text { References to interactions with and orientations } \\
\text { toward curriculum materials in respect to } \\
\text { contextual factors. Includes students, school } \\
\text { culture, community, standards, etc. }\end{array}$ \\
\hline $\begin{array}{l}\text { Interactions with curriculum } \\
\text { materials toward teacher learning }\end{array}$ & $\begin{array}{l}\text { References to interactions with and orientations } \\
\text { toward curriculum materials in respect to } \\
\text { teacher-oriented practice. Includes iterative } \\
\text { cycles of planning, enactment, and reflection, } \\
\text { subject-matter support, pedagogical learning, } \\
\text { etc. }\end{array}$ \\
\hline $\begin{array}{l}\text { Perspectives on the nature of } \\
\text { curriculum materials }\end{array}$ & $\begin{array}{l}\text { Definitions of curriculum and curriculum materials, } \\
\text { how these are similar./different, purposes of } \\
\text { curriculum materials, teachers' relationship with } \\
\text { curriculum materials }\end{array}$ \\
\hline $\begin{array}{l}\text { Perspectives on the nature of } \\
\text { science teaching practice }\end{array}$ & General views on science teaching \\
\hline \multicolumn{2}{|c|}{ Origins of curricular role identity } \\
\hline Personal history as learners & $\begin{array}{l}\text { Influence of preservice teachers' experiences as } \\
\text { students of science on their interactions with and } \\
\text { orientations toward curriculum materials }\end{array}$ \\
\hline Classroom-based experience & $\begin{array}{l}\text { Influence of preservice teachers' experiences as } \\
\text { observing and practicing teachers in elementary } \\
\text { classrooms on their interactions with and } \\
\text { orientations toward curriculum materials }\end{array}$ \\
\hline TE program methods class & $\begin{array}{l}\text { Influence of preservice teachers' experiences in } \\
\text { the methods course on their interactions with and } \\
\text { orientations toward curriculum materials }\end{array}$ \\
\hline
\end{tabular}

\section{TABLE 2}

\section{Changes in Self and Role Scores for Whole Survey}

\begin{tabular}{|c|c|c|c|c|c|c|}
\hline & \multicolumn{2}{|c|}{ Beginning of the Semester } & \multicolumn{2}{|c|}{ End of the Semester } & \multirow[b]{2}{*}{$t$-Test } & \multirow[b]{2}{*}{ Effect Size } \\
\hline & Mean & Standard Deviation & Mean & Standard Deviation & & \\
\hline Self & 2.8247 & 0.42059 & 3.0858 & 0.43139 & $-4.346^{\star \star \star}$ & 0.6128 \\
\hline Role & 3.0589 & 0.38804 & 3.2087 & 0.42440 & $-2.348^{*}$ & 0.3684 \\
\hline$t$-Test & & $-3.961^{\star \star \star}$ & & $-2.378^{\star}$ & & \\
\hline Effect size & & 0.5788 & & 0.2872 & & \\
\hline
\end{tabular}

${ }^{\star \star *} p<.001,{ }^{\star \star} p<.005,{ }^{\star} p<.05$. 


\section{TABLE 3}

\section{Changes in Self and Role Scores for Dimension 1: General Use of Science Curriculum Materials}

\begin{tabular}{|c|c|c|c|c|c|c|}
\hline & \multicolumn{2}{|c|}{ Beginning of the Semester } & \multicolumn{2}{|c|}{ End of the Semester } & \multirow[b]{2}{*}{$t$-Test } & \multirow[b]{2}{*}{ Effect Size } \\
\hline & Mean & Standard Deviation & Mean & Standard Deviation & & \\
\hline Self & 2.6778 & 0.49607 & 2.9684 & 0.58807 & $-3.172^{\star \star}$ & 0.5341 \\
\hline Role & 2.9113 & 0.54402 & 3.1167 & 0.54512 & $-2.536^{\star}$ & 0.3771 \\
\hline$t$-Test & & $-2.597^{\star}$ & & -1.911 & & \\
\hline Effect size & & 0.4485 & & 0.2615 & & \\
\hline
\end{tabular}

${ }^{* * *} p<.001,{ }^{* *} p<.005,{ }^{*} p<.05$.

difference between self and role scores at the end of the semester was smaller than at the beginning, there remained a statistically significant difference between the two. This analysis suggests that they had more closely, but not fully, appropriated a curricular role identity that they perceived to be that of expert practitioners.

These aggregate data, however, do not tell the whole story. To shed light on the preservice teachers' curricular role identity development for science teaching, results for each of the four dimensions of curricular role identity are presented in the sections that follow.

\section{Dimension 1: Curricular Role Identity for General Use of Science Curriculum Materi-}

als. Dimension 1, general use of science curriculum materials, is defined as preservice teachers' orientations toward and use of science curriculum materials for students' activities, information provided for teachers, and overall presentation and organization. For example, a task in this dimension might include evaluating an existing science lesson plan based on how well it compares to a teacher's expectations for lesson plan organization, such as explicitly stated learning goals or suggestions for engaging students in a whole-class discussion. Statistics for self and role scores are presented in Table 3.

At the beginning of the semester, the preservice teachers reported a fundamental difference between experienced elementary teachers' generalized curricular role identity and their own. Both self and role scores increased over the course of the semester and, by its end, there was no statistically different difference between the two. These results show that the preservice teachers came to appropriate the generalized curricular role identity that they attributed to experienced elementary teachers.

Findings from the eight focal preservice teachers suggest that over the course of the semester, they came to view the active use of science curriculum materials as an important dimension of elementary teaching practice. They all noted that in previous teacher education courses they had had the opportunity to construct their own lesson plans. However, they had little to no experience specifically critiquing and modifying existing curriculum materials. As Don reflected, "this is the first time I actually looked at other peoples' lesson and wanted to change it ... basically my whole career here I've had to create my own, I haven't really looked at anybody else's" (Don, Interview 1, 595-604). ${ }^{1}$ This was particularly the case for curriculum materials that they themselves had not initially designed and constructed. For example, in anticipating the upcoming reflective teaching assignments early in the semester,

\footnotetext{
${ }^{1}$ Quotes from participant interviews are labeled as name [pseudonym], Interview [interview \#], [line number(s) from transcribed document].
} 


\begin{abstract}
Alison said,
I've had to modify my own lessons but in a very basic way. If I taught it I'd kind of reflect on how to modify it. So the assignment that's coming up where I take my teacher's lesson and modify that, I've never experienced that before. It's always been I create something then modify it later, so this will be very interesting, I'm excited about it. (Alison, Interview $1,527-542)$
\end{abstract}

For most of the preservice teachers, the emphasis in the science methods course on critiquing and modifying existing curriculum materials was a new experience. In particular, they placed importance on the social nature of curriculum materials use in the methods course and opportunities to critique others' curricular decision making as well as their own.

At the beginning of the semester, many of the preservice teachers expressed a lack of confidence in critiquing and adapting curriculum materials. Sally, for example, reflected that she had "been a little bit more timid about altering [curriculum materials] and about knowing... what would be best for students and what's out there as resources" (Sally, Interview 2, 966-969). Through their methods- and classroom-based experiences, however, the preservice teachers came to perceive themselves as better able to engage in curriculum design practices. By the end of the semester, Sally reported feeling as though she had grown more confident due to "the experience of working with a whole bunch of different lessons and being able to critique and talking to other people about how they change their lesson" (Sally, Interview 2, 979-982). Patrice also reflected on her developing perspective on this essential dimension of teaching practice and noted how it had changed.

I've realized that if you don't really care, I mean you're like okay, here's my lesson, let's teach it, but if you really want, if you really care about it and you really want your students to learn the science in the correct way... and clear up misconceptions then you would look at lessons differently. I'm just realizing that. There's a lot involved in it too. I didn't really think about, because I haven't ever taught science before, I didn't really think about modifying lessons. Throughout this semester I've realized that it is important that you look at your lessons before and see really what you want your kids to know after the lesson. (Patrice, Interview 2, 850-877)

The preservice teachers began to view student learning as fundamentally tied to their own instructional planning, particularly the critique and adaptation of science curriculum materials.

Despite their developing awareness of the importance of adapting science curriculum materials, the preservice teachers also noted that they expected the nature of this activity to change as they gained experience in the classroom. The curriculum materials focused activities in the methods course, and the lesson plans the preservice teachers were asked to construct were detailed and comprehensive though, as Wendy suggested, "real teachers probably don't do all of this" (Wendy, Interview 2, 982-983). They drew a fundamental distinction between how inexperienced and more experienced teachers engage with curriculum materials, appropriating a role standard in which the critique and adaptation of curriculum materials is a less necessary dimension of practice. For example, Alison noted,

... having to plan out that whole lesson plan, figure out all those different like context and writing out your whole instructional sequence, it's good to do that for right now. I don't think I'll do that as much student teaching ... or when I'm teaching but I understand why we're doing it now. I feel like I'll probably skip over a lot of the things... and I know exactly what happens before and what's going to happen after, I feel like, I won't have to write everything down, I would just know. I would probably still jot [my instructional sequence] down, just not in as much detail ... because, any time I write anything scripted 
I never say that anyway ... so I guess a little skimpier in the lesson planning. I would have it internalized. (Alison, Interview 2, 440-468)

The preservice teachers, then, not only developed increasing confidence in their ability to critique and adapt curriculum materials but also came to view it as an authentic dimension of teaching practice. The detailed and comprehensive curriculum design processes they were asked to undertake in the methods course helped them develop the capacity to engage in the less involved forms of curriculum design that they expected to undertake as practicing teachers.

Dimension 2: Curricular Role Identity for Scientific Inquiry. Dimension 2, curricular role identity for scientific inquiry, is defined as preservice teachers' orientations toward and use of science curriculum materials to promote inquiry, including students' use of questioning, prioritization of evidence, explanation construction, and accounting for students' existing ideas. For example, an activity in this dimension might include modifying an existing science lesson by adding an investigation question or explicit supports for students' data collection. Statistics for self and role scores are presented in Table 4.

Similar to the survey results for Dimension 1, for Dimension 2, curricular role identity for scientific inquiry, the preservice teachers also articulated a fundamental difference between their curricular role identity and that of experienced elementary teachers at the beginning of the semester. Over the course of the semester, they constructed a curricular role identity for scientific inquiry that was more aligned to that which they attributed to experienced elementary teachers and, by the end of the semester, there was no statistically significant difference between the two. However, unlike Dimension 1, their conceptions of experienced elementary teachers' curricular role identity for scientific inquiry did not fundamentally change. This suggests that while the preservice teachers were able to appropriate what they perceived to be experienced teachers' curricular role identity for scientific inquiry, their perceptions of the latter were stable.

Since developing knowledge and abilities related to inquiry-oriented science teaching and the use of science curriculum materials are two of three major goals of the elementary science methods course, the preservice teachers simultaneously worked to construct an operational understanding of scientific inquiry and learn how to instantiate these understandings in the curriculum materials they developed. However, the data from the smaller subset of teachers suggests they did this in very different ways. This was largely a function of the science curriculum materials they used, their own orientations toward and understanding of inquiry, and their opportunities for science teaching in their placements.

The types of science curriculum materials the preservice teachers had to work with in planning for their lessons differed substantially. Many had access to inquiry-oriented science curricula, either from major publishers or district-created science curricula. All the

\section{TABLE 4}

\section{Changes in Self and Role Scores for Dimension 2: Scientific Inquiry}

\begin{tabular}{|c|c|c|c|c|c|c|}
\hline & \multicolumn{2}{|c|}{ Beginning of the Semester } & \multicolumn{2}{|c|}{ End of the Semester } & \multirow[b]{2}{*}{$t$-Test } & \multirow[b]{2}{*}{ Effect Size } \\
\hline & Mean & Standard Deviation & Mean & Standard Deviation & & \\
\hline Self & 2.9574 & 0.5905 & 3.2667 & 0.51235 & $-3.617^{\star \star \star}$ & 0.5595 \\
\hline Role & 3.3245 & 0.51582 & 3.4129 & 0.53033 & -1.027 & 0.1689 \\
\hline$t$-Test & & $-4.236^{\star \star \star}$ & & -1.822 & & \\
\hline Effect size & & 0.6621 & & 0.2804 & & \\
\hline
\end{tabular}

${ }^{\star * *} p<.001,{ }^{* *} p<.005,{ }^{*} p<.05$. 
preservice teachers had access to science curriculum materials from the Curriculum Access System for Elementary Science Web site (CASES; Davis, Smithey, \& Petish, 2004) though they varied in the extent to which they drew upon them. Others, however, had little in the way of formal science curricula in their classroom placements and relied on scant resources from their cooperating teachers and outside resources. This had a significant impact on their critique and adaptation of existing curriculum materials. Those who initially undertook instructional planning with inquiry-oriented curriculum materials generally found it easier to make additional modifications focused on scientific inquiry. For example, Don said,

The process of making my ... lesson inquiry-based was quite easy. I modified a lesson that is posted on CASES. It was already based on inquiry and I just added to it to make it more of an inquiry lesson that I thought was more effective. (Don, Online discussion, $11-10-2005,185-187)^{2}$

When the preservice teachers used less inquiry-oriented curriculum materials, or nothing at all, they often struggled to instantiate their own understandings of inquiry in the lessons they developed. Take Serena as an example. In her first reflective teaching lesson, she used an existing lesson from the Full Option Science System (FOSS) science curricula, which her district uses for elementary science. For her, as with Don's use of CASES curriculum materials previously, the use of the FOSS lesson helped her construct an even more inquiry-oriented science lesson.

I didn't have as difficult a time as some making my lesson inquiry-based because it was from the FOSS kit so it was already very inquiry-based. I only made a few modifications to make it more inquiry based. Using the FOSS kit definitely made my job a lot easier and helped guide my lesson in a very inquiry based direction. (Serena, Online discussion, $11-09-2005,125-130)$

However, in her second reflective teaching assignment, Serena used a lesson her cooperating teacher had gotten online. Unlike the FOSS lesson Serena had modified for her first reflective teaching assignment, the second lesson plan "just had the standards, ... a brief list of materials, and. . . the directions, and that was it" (Serena, Interview 2, 113-118). In addition, she noted there were some inaccuracies in the lesson's representation of the layers of the Earth that made it "a little more difficult" and "threw off the whole lesson." As a result, she said that her second lesson was much less inquiry oriented than the first, in large part as a result of the original lesson being much less inquiry oriented than the FOSS lesson she used previously.

The preservice teachers' own orientations toward science, science teaching, and inquiry also played a role. Planning for and enacting inquiry-oriented lessons proved to be a fundamental motor for the preservice teachers' inquiry-oriented learning and identity development. Using inquiry-oriented curriculum materials, in Don's words, helped "me understand. . . inquiry-based lessons a little more [because] I could actually see it first hand" (Don, Online discussion, 11-10-2005, 189-190). The preservice teachers often noted what they perceived to be improvement between their first and second reflective teaching experiences. Kelly, for example, said "my second lesson was definitely more inquiry-oriented than the first, so I am learning and improving upon this teaching approach" (Kelly, Online discussion, 11-08-2005, 16-18). Owing to her self-perceived lack of science subject-matter knowledge, Shannon recalled that her first reflective teaching experience was "a very difficult experience for me... I ended up being a nervous wreck when it came time to get in

\footnotetext{
${ }^{2}$ Quotes from participants' online discussions are labeled as name [pseudonym], Online discussion, [date], [line number(s) from transcribed document].
} 
front of my class!" (Shannon, Online discussion, 11-10-2005, 230-231). However, after developing a highly inquiry-oriented, multiday investigation from a variety of curriculum materials for her second reflective teaching lesson, she noted how much better prepared she felt to use curriculum materials for inquiry, saying,

I guess it was just the fact that I was able to create my own lesson. The fact that I basically changed a lot about my second lesson. I formed my own, it was the majority of my own ideas that put it together and it went so nicely. It's kind of an ego booster. I know that I can make a good lesson and the kids are interested in it. I know that if I should end up having to teach my own science lessons that I can do it, I'm capable. (Shannon, Interview $2,443-462)$

However, many of the preservice teachers found their opportunities to enact the inquiryoriented science lessons they developed were constrained by the degree to which science was being taught in their placement classrooms. While the preservice teachers described their growing understanding of what inquiry-oriented science teaching looks like and how to engage in it, they often also noted that they did not often observe such science-teaching practices in their placement classrooms, even in classrooms where science was taught regularly. In reflecting upon his two reflective teaching lessons at the end of the semester, Don said, "I just felt that they went really well and I'm glad we got to do it because I just didn't know what kind of ways of teaching science there are ... I would love to be able to see [inquiry], but we don't" (Don, Interview 2, 30-33). The preservice teachers attributed the relative absence of opportunities to observe inquiry-oriented science teaching to a deprioritization of science in relation to other subjects, most often due to in-class preparation for standardized assessments or a prioritization of other subjects, particularly mathematics and reading. This not only had an impact on their opportunities to observe inquiry-oriented science teaching but also constrained their ability to develop inquiry-based lessons to teach. Kelly wrote late in the semester,

It seems that science is always playing second fiddle to math in my classroom. Although I've seen many science lessons taught, they are the first to get cut down when time is tight. My [cooperating teacher] was happy to let me teach my [reflective teaching assignment lessons], but the lessons I taught were very specific and she gave me the materials to use. Although it was great to have these resources and support for my first time planning inquiryoriented lessons, I feel like it was a double-edged sword almost. I did not want to stray too far from what my [cooperating teacher] needed for her unit and what she wanted the students to learn. I wanted to make sure I touched on all of her unit requirements and plans, and therefore, I felt like it was difficult to completely turn a lesson into an inquiry-based approach. I did my best to make this work, but I think this process will be easier to apply to science when we are actually teaching on a more consistent basis (i.e., next semester in student teaching). (Kelly, Online discussion, 11-08-2005, 19-25)

While their experiences over the course of the semester did not fundamentally change their conceptions of how experienced elementary teachers engage with science curriculum materials to promote inquiry, the preservice teachers did make strides in more closely appropriating the curricular role identity they attributed to more experienced teachers.

Dimension 3: Curricular Role Identity for Curriculum Materials' Use in Context. Dimension 3, curricular role identity for context, is defined as preservice teachers' orientations toward and use of science curriculum materials in regard to contextual affordances and constraints, such as standards and benchmarks, student characteristics, and resource 


\section{TABLE 5}

\section{Changes in Self and Role Scores for Dimension 3: Curriculum Materials'} Use in Context

\begin{tabular}{|c|c|c|c|c|c|c|}
\hline & \multicolumn{2}{|c|}{ Beginning of the Semester } & \multicolumn{2}{|c|}{ End of the Semester } & \multirow[b]{2}{*}{$t$-Test } & \multirow[b]{2}{*}{ Effect Size } \\
\hline & Mean & Standard Deviation & Mean & Standard Deviation & & \\
\hline Self & 2.7819 & 0.47952 & 3.0593 & 0.45951 & $-4.389^{\star}$ & 0.5906 \\
\hline Role & 3.1915 & 0.48402 & 3.2871 & 0.48387 & -1.316 & 0.1975 \\
\hline$t$-Test & & $-5.375^{\star}$ & & $-3.926^{*}$ & & \\
\hline Effect size & & 0.8502 & & 0.4827 & & \\
\hline
\end{tabular}

${ }^{\star \star \star} p<.001,{ }^{* \star} p<.005,{ }^{*} p<.05$.

availability. For example, an activity in this dimension might include adapting an existing science lesson to align with district-level curricular objectives or in light of investigation materials to which a teacher does not have access. Statistics for self and role scores are presented in Table 5 .

Similarly to Dimensions 1 and 2, the preservice teachers reported a significant difference between the curricular role identity for context that they attributed to experienced elementary teachers and that they attributed to themselves at the beginning of the semester. They also became more attuned to these contextual factors and more fully incorporated them in their own curricular role identity by the end of the semester. As in Dimension 2, however, their conceptions of experienced elementary teachers' curricular role identity for context did not fundamentally change over the semester. Most importantly, however, and unlike any of the other dimensions measured but consistent with the aggregate survey results, there remained a statistically significant difference between self and role scores at the end of the semester. This suggests that while the preservice teachers increasingly viewed these contextual factors as important influences on their use of curriculum materials, by the end of the methods course they still had not fully appropriated the curricular role identity for context that they attributed to more experienced elementary teachers.

Qualitative data from the focal preservice teachers suggest this observed difference at the end of the semester was largely due to the preservice teachers' preexisting notions about what experienced elementary teachers do with curriculum materials, as well as the inherent fluidity of their own contexts for learning to teach. Overall, the preservice teachers acknowledged the importance of accounting for these contextual features in their curriculum design for inquiry-oriented science teaching. For example, and arguably most important, they each made the crucial link between the needs of students and their use of curriculum materials for science, seeing the former as a fundamental force driving the latter. As Sally said,

I think especially with changing classes and the kids and just the dynamic they bring to a classroom that you'd have to change [curriculum materials] to make it really valuable to every set [of students]. I may be more comfortable in teaching ten years after but I think that you may even have some kind of rotating thing where I might go back to something I did the third year that I thought wasn't good, but now it is for this group of kids again. . I I think it almost should change from year to year because, you know kids are so different. (Sally, Interview 2, 335-342)

District-level curriculum standards were a particularly important consideration for the preservice teachers' learning to account for context as they engaged in curriculum design for science. Evidence suggests that the preservice teachers had fully appropriated the 
expected role science standards and benchmarks would play in their curriculum design efforts for science early in the semester. For example, 2 weeks into the course, Kelly wrote,

... they give such important guidance that us first year teachers need. Once we get into schools and actually start teaching, most of our buildings will have either personalized standards or district wide standards that are based on the state and national standards. This will help us navigate through the standards and really see what we need to touch on in our lessons. I don't look at standards as limiting and the end-all of what we must teach, but rather as guideposts to what our students should eventually understand through our "creative and individualized" lessons. (Kelly, Online discussion, 09-21-2005, 171-178)

While they each noted the important influence of state and national standards on their teaching practice, experiences in their placement classrooms reinforced the idea that local standards have a much more direct influence on day-to-day instructional planning. As Don said, "I feel that when you're in the district you should follow what the district tells you" (Don, Interview 1, 283-284).

However, because the preservice teachers had only been in their placement classrooms since the beginning of the semester, they had a relatively limited time in which to develop a deep understanding of the school-specific particulars that mediated their curriculum design efforts. For example, many of the preservice teachers had limited opportunities to work directly with relevant science standards in their instructional planning during the semester. Sally described her experience early in the semester, saying, "I haven't actually seen and worked with [science standards] and how my teacher. . . how long it would actually take to do each one and what kind of a goal she's setting for herself" (Sally, Interview 1, 511518). In many cases, the preservice teachers were left to infer what learning objectives were specified in relevant science standards through the instructional goals and curriculum materials provided to them by their cooperating teachers. Wendy recalled her first reflective teaching lesson, saying,

I just saw this folder that [my cooperating teacher] showed me, I think it is definitely following the standards... she hasn't talked about it. I'm guessing that they're standards just because it just seems formal but it very well might be her own organization or something like that. But no, she hasn't really talked to me about them. If those are the standards I think she is following it pretty closely because she makes these lessons based on them. (Wendy, Interview 1, 616-625)

While the preservice teachers clearly prioritized the importance of accounting for students and curriculum standards in their use of curriculum materials, the nature of their classroom placements limited the degree to which they could translate these broad principles of practice into specific actions. Here again, the preservice teachers noted a disconnect between the type of instructional planning in which they engaged in the methods course and that which they expected to undertake as practicing teachers. A fundamental difference between the two revolved around their own immersion in, and experience with, contextual features of particular classroom contexts, including students, availability of resources, and particular standards they would be expected to address. As Alison noted about the lesson plans she and the other preservice teachers were asked to construct for the science methods course, "I wouldn't need to write down [information about] my context because I'm in the middle of it" (Alison, Interview 2, 462-464). As a result, they were unable to fully appropriate the curricular role identity for use of curriculum materials in context that they attributed to more experienced elementary teachers. 
TABLE 6

Changes in Self and Role Scores for Dimension 4: Teacher Learning from Curriculum Materials

\begin{tabular}{|c|c|c|c|c|c|c|}
\hline & \multicolumn{2}{|c|}{ Beginning of the Semester } & \multicolumn{2}{|c|}{ End of the Semester } & \multirow[b]{2}{*}{$t$-Test } & \multirow[b]{2}{*}{ Effect Size } \\
\hline & Mean & Standard Deviation & Mean & Standard Deviation & & \\
\hline Self & 2.8777 & 0.47455 & 3.0427 & 0.48476 & $-2.061^{*}$ & 0.3439 \\
\hline Role & 2.8334 & 0.45276 & 3.0129 & 0.48275 & $-2.424^{*}$ & 0.0616 \\
\hline$t$-Test & & 0.626 & & 0.437 & & \\
\hline Effect Size & & 0.0955 & & 0.0616 & & \\
\hline
\end{tabular}

${ }^{* \star *} p<.001,{ }^{* \star} p<.005,{ }^{*} p<.05$.

\section{Dimension 4: Curricular Role Identity for Teacher Learning From Curriculum Materi-}

als. Dimension 4, curricular role identity for teacher learning, is defined as preservice teachers' orientations toward and use of science curriculum materials in regard to their own pedagogical and subject-matter learning. For example, an activity in this dimension might include critiquing an existing lesson based on what content supports it provides teachers or developing pedagogical content knowledge through iterative cycles of lesson enactment and refinement. Statistics for self and role scores are presented in Table 6.

Unlike the other three dimensions of curricular role identity measured, the preservice teachers did not articulate a fundamental distinction between experienced teachers' and their own curricular role identity in respect to learning from curriculum materials, either at the beginning or end of the semester. However, both self and role scores increased significantly over the course of the semester, suggesting that the preservice teachers developed a more learning-oriented curricular role identity both for themselves and experienced elementary teachers. In short, they came to view the capacity for learning from science curriculum materials as a more fundamental part of teaching for all elementary teachers.

Science subject-matter knowledge was, not surprisingly, a primary concern for the preservice teachers. Most of the preservice teachers expressed concerns about their own understanding of particular science concepts. For example, Alison noted,

I kind of feel like [teachers] need to know a little bit of everything ... and that's why I feel like I'm lacking in that area because I just don't have a good base knowledge of science ... so I feel like I do need just to learn even the basic things that these elementary students are learning again ...I worry about answering questions that students would have, not really answering them correctly and I don't even know if I have preconceptions that haven't really been cleared up yet. (Alison, Interview 1, 149-161)

In light of these self-described limitations of their subject-matter knowledge, the preservice teachers each suggested that science curriculum materials could serve as important subjectmatter supports. As Patrice said, "I think teachers can definitely learn from the content in the curriculum" (Patrice, Interview 1, 111). However, they also suggested that extensive subject-matter background was often not included in science curriculum materials they used. Shannon said, "I think pretty much the only place that I found lessons that had teacher background was on CASES" (Shannon, Interview 2, 772). As a result, they expected to have to draw from a variety of resources to increase their own subject-matter knowledge. Patrice continued,

... [teachers] can get a lot more content from like other places too. They can use different resources. I think if they want to get like the basic stuff they have to teach they can get it 
off the curriculum, but if they want to like enhance their knowledge ... at a deeper level I guess I'm trying to say ... they can get that from other resources. (Patrice, Interview 1, $112-116)$

However, while acknowledging the value of features of the curriculum materials that could support their subject-matter knowledge, the preservice teachers suggested that these supports are less important for experienced teachers. As Alison suggested,

I would say that's more for beginner teachers, because after you've taught something for a while ... you tend to know it really well. It's always good to find out new information $\ldots$, but I do feel that after time things begin to stick in your brain too. And generally you're given a little bit of information in every lesson, so that can get you started. (Alison, Interview 2, 705-710)

However, while the preservice teachers drew fundamental distinctions between the curriculum design activities they engaged in as part of the methods course and those they expected to engage in as practicing teachers, they also noted that curriculum materials could act as crucial supports for experienced teachers in two specific situations: when teaching new content and/or using new curriculum materials.

Even experienced teachers often find themselves teaching new content. In such cases, the preservice teachers suggested that curriculum materials could support experienced teachers too. Kelly, for example, was placed in a classroom with a cooperating teacher who had many years of teaching experience but had just returned to the classroom after an extended absence. She recalled a science lesson she observed her cooperating teacher teaching on vertebrates and invertebrates, saying,

We're sitting there and all of a sudden my cooperating teacher goes "I don't know, is an octopus a vertebrate or an invertebrate?," [she said] "it's been so long since I've actually thought about this, I don't know." She said "[Kelly] is going to help us, teachers sometimes forget so [Kelly] is going to go online and double-check for us so we can make sure that we have, we're giving you the correct information." She said we should have looked over this before I did it. She's like "I just thought this would be a great activity and I looked and I saw so many mammals and insects" and I thought, oh I know. I think in that case you're not getting any guidance from the curriculum materials. (Kelly, Interview 1, 404-423)

Kelly highlighted how curriculum materials can support teachers' science-teaching practice but, in this situation, did not. While the preservice teachers placed greater importance on the capacity of science curriculum materials to support the subject-matter learning of beginning teachers rather than of experienced teachers, they nevertheless recognized situations in which even experienced teachers find themselves with a less robust grasp of particular science content than would be desired.

Similarly, the preservice teachers noted the value of supports for teachers in curriculum materials when they are first learning to use those particular materials. Each of the eight preservice teachers experienced a wide variety of science curriculum materials in his or her placement schools and classrooms and was working with cooperating teachers who had been using their science curriculum materials for some time. However, each of them also had an opportunity to observe their cooperating teachers using the Everyday Mathematics curriculum for mathematics teaching. For most of their cooperating teachers, these curriculum materials had only been recently introduced and they were still in the early stages of transitioning from prior mathematics curricula to Everyday Mathematics. The preservice teachers described many challenges their cooperating teachers experienced in making this transition, as well as how they and other teachers at their schools and taken an active role 
in integrating the new mathematics curriculum materials into their teaching practice. For example, Wendy recalled,

... [my cooperating teacher] was saying how overwhelming it was at first but, one of the other fifth grade teachers and she, they went through it and broke it down and went week by week, this is what we need to finish by the end of this week, by the end of this week and so when it was in week sets like that um, she could see where she was and she could like pace herself better. (Wendy, Interview 2, 948-952)

The preservice teachers, therefore, got to see firsthand, albeit not for science, how the implementation of a new curriculum requires even experienced teachers to reconfigure their subject-specific teaching practice. While their experiences with the implementation of new curriculum materials was in a subject other than science, it nonetheless influenced their developing sense of how elementary teachers at various stages along the teacher professional continuum learn to use new curricular resources. As Wendy noted later in the semester, "when curriculum changes you're going to have to adjust to that and learn how to use a new one. So it's kind of like [being] in the same boat as a new teacher" (Wendy, Interview 2, 986-990).

\section{Summary of Results}

Through their use of science curriculum materials over the course of the semester, the preservice teachers actively engaged in the construction of a curriculum-specific role identity for elementary science teaching. As illustrated in these findings, the preservice teachers made significant gains toward appropriating the curricular role identity they attributed to more experienced elementary teachers and closely, but not always fully, appropriated this expert curricular role identity. They were able to appropriate what they perceived to be experienced teachers' curricular role identity for scientific inquiry. They increasingly viewed contextual factors as important factors of their use of curriculum materials, though by the end of the methods course they still had not fully appropriated the curricular role identity for context that they attributed to more experienced elementary teachers. The preservice teachers viewed preservice and experienced elementary teachers' capacity to learn from science curriculum materials as comparable, though primarily emphasized subject-matter learning, and constructed a more learning-oriented curricular role identity over the course of the semester.

\section{DISCUSSION}

The results presented here show that these preservice elementary teachers actively engaged in curricular role identity construction through their work with science curriculum materials. Because the science methods course emphasized the critique, adaptation, and use of science curriculum materials, and due to the foundational role such resources play in classroom teaching, a crucial aspect of "becoming a teacher" involved negotiating the use of science curriculum materials as a constituent piece of learning. Our findings suggest that the preservice teachers explicated a role standard (Collier, 2001; Stets \& Burke, 2000) and translated these role standards into designated identities (Sfard \& Prusak, 2005).

A consistent finding in this study is that the preservice teachers' role identities, the self scores on the survey and other reifications of "who they are" as developing elementary teachers, were more fluid and subject to change than were the curricular role identities they 
attributed to experienced elementary teachers. Through their work with science curriculum materials in the methods course and their placement classrooms, they were able to more closely appropriate their designated curricular role identity by the end of the semester. These results reinforce the importance of teacher characteristics, including identity, in teachers' interactions with curriculum materials (Remillard, 2005) and further illuminate teacher learning at the preservice stage along the teacher professional continuum (Feiman-Nemser, 2001). They also further inform the field's understanding of identity in transition (Lemke, 2000) by illustrating how preservice elementary teachers' conceptions of themselves as elementary teachers evolve related to curriculum-specific aspects of science-teaching practice.

Within each of the constituent dimensions of curricular role identity, however, this overall trend differed. This suggests that curricular role identity is not a singular global self-concept but a composite representation of multiple activities teachers engage in and that its development is subject to meaning making across these particular activities. The results from this study, therefore, support a differentiated view of role identity (Collier, 2001), where role identity construction involves the various dimensions that constitute meaning for the role itself. Specifically, the findings suggest the importance of differentiating among those dimensions of curricular role identity for science teaching defined here and, more generally, of the teacher-curriculum relationship.

For the preservice teachers, expectations for curriculum design processes often differed between the methods course and classroom contexts. Throughout the study, the preservice teachers acknowledged, correctly, that the type of in-depth, detailed work with science curriculum materials they undertook in the methods course would likely not be the same as that which they would engage in as practicing teachers. As such, the preservice teachers largely constructed curricular role identities for science teaching in light of perceived and real demands of classroom teaching and the practices of their more experienced cooperating teachers. Together, these constitute figured worlds of elementary classrooms for which the preservice teachers were being prepared (Boaler \& Greeno, 2000; Graue, 2005; Kozoll \& Osborne, 2003). These findings illustrate the primacy of role appropriation over role negotiation and the important influence of practicing teachers as "significant narrators" (Sfard \& Prusak, 2005) in preservice teachers' role identity development, thus reinforcing the institutional, discursive, and affinity-based origins of role identity (Gee, 2000-2001). At the same time, however, our findings also suggest that both teacher education and classroom contexts can contribute to preservice teachers' curricular role identity development.

The preservice teachers often highlighted the internalization of the curriculum design process that they associated with their cooperating teachers as a defining characteristic of teaching expertise. It is this internalization and routinization of knowledge in practice that some argue differentiates between novices and experts (Bransford, Brown, \& Cocking, 2000) and mark transitions from novice to expert teachers along the teacher professional continuum (Feiman-Nemser, 2001; Richardson, 1996). Unfortunately, teachers often struggle to articulate such tacit knowledge (Berliner, 1986; Hiebert, Gallimore, \& Stigler, 2002; Roth, 1998), a common issue in many activity settings (Hutchins, 1995; Lave \& Wenger, 1991). Curriculum materials, however, as artifacts of practice, can serve as an important vehicle for the representation of teachers' expertise (Ball \& Lampert, 1999; Shulman, 1986). This is especially the case for educative curriculum materials that can help teachers make rationales underlying their instructional decisions explicit. It is, therefore, crucial that preservice teachers be supported to develop a curricular role identity in which curriculum materials are both valued as pedagogical tools and as artifacts through which to reify principles of practice generated through science teaching. 


\section{Implications for Science Teacher Education}

These findings support the need to emphasize opportunities for preservice teachers to critique, adapt, enact, and revise science curriculum materials as part of their teacher education experiences (Davis, 2006; Dietz \& Davis, in press; Schwarz et al., in press). In our methods course, we prioritize preservice teachers' learning to use science curriculum materials and provide multiple and varied opportunities for them to apply their developing knowledge to the critique and adaptation of existing science curriculum materials. We also provide preservice teachers multiple opportunities to engage in these curriculum design processes around science lessons they actually enact in their elementary classrooms (see Davis, 2006, for a more thorough discussion of these instructional approaches). These opportunities provide a crucial set of experiences across contexts through which preservice teachers can develop their capacity for pedagogical design.

However, these findings also help identify particular areas that can be more adequately addressed through preservice teachers' experiences in elementary classrooms. The preservice teachers here were not successful in appropriating the curricular role identity for Dimension 3, accounting for context in their use of curriculum materials. One explanation for this is that the relatively short-term classroom-based field experiences do not afford preservice teachers the same opportunities to develop the kind of rich, in-depth appreciation for the features of particular classroom and school settings, as well as groups of students, that they do full-time practicing teachers. Similarly, preservice teachers benefit from observing experienced teachers teach science as inquiry (Eick, Ware, \& Williams, 2003). However, the preservice teachers here reported having limited opportunities to observe or engage fully in inquiry-oriented teaching. Their conceptions of experienced elementary teachers' use of science curriculum materials to promote inquiry practices (Dimension 2) did not change significantly over the course of the semester.

This implies, of course, that preservice teachers would benefit from longer term, stable field experiences that afford such opportunities (Clift \& Brady, 2005). However, deep immersion in authentic school settings can sometimes work against the reform-oriented approach to science teaching being promoted by teacher educators by exposing preservice teachers to often contradictory dominant cultures of schools (Putnam \& Borko, 2000). To promote coherent identity development across teacher education and classroom contexts, more consistency between teacher education and classroom-based experiences for preservice teachers is necessary (Putnam \& Borko, 2000; Zeichner \& Conklin, 2005).

Identity exists not only in its representational form but also in the activities in which teachers engage (Enyedy et al., 2006; Lemke, 2000; Sfard \& Prusak, 2005). If preservice teachers are to develop a curricular role identity, for example, in which they are able to effectively mobilize and use curricular resources in light of setting-specific curricular objectives and student needs, they need to have opportunities to learn to do so in elementary classrooms. Similarly, if they are to construct an appropriate role standard or designated identity for the use of science curriculum materials to promote inquiry practices in elementary science classrooms, they need to observe practicing teachers, their "significant narrators," engaging in such practices. Classroom-based field experiences must, therefore, provide preservice teachers with opportunities to actively translate their developing knowledge, skills, and identities into authentic teaching practice so that they can construct a curricular role identity for elementary science teaching that is consistent with the field's definition of effective, standards-based, inquiry-oriented science teaching (AAAS, 1993; NRC, 1996, 2000). While our work focuses on preservice elementary teachers, we hypothesize that these recommendations are also consistent with the needs of preservice middle and secondary science teachers (Eick et al., 2003; Windschitl, 2003). 


\section{Implications for Science Curriculum Development}

The preservice teachers in this study constructed a curricular role identity in which they saw science curriculum materials playing an important role for beginning teachers and, to a lesser extent, experienced teachers. Even though they did not perceive curriculum materials to be equally important tools for experienced teachers, they all suggested that curriculum materials were important supports for experienced teachers in two cases: when they were using those curriculum materials for the first time and when they were teaching new content. These findings reinforce the important role curriculum materials play in supporting beginning teachers' practice (Forbes \& Davis, submitted for publication; Kauffman, Johnson, Kardos, Liu, \& Peske, 2002; Valencia, Place, Martin, \& Grossman, 2006), as well as for more experienced teachers in the context of curriculum-based science education reform (Barab \& Luehmann, 2003; Fishman \& Krajcik, 2003; Roehrig \& Kruse, 2005; Schneider et al., 2005).

To better support beginning and experienced teachers' learning, it is crucial for curriculum developers to design science curriculum materials that support their science-teaching practice by making them flexibly adaptive (Barab \& Luehmann, 2003; Fishman \& Krajcik, 2003; Schwartz, Lin, Brophy, \& Bransford, 1999; Squire, MaKinster, Barnett, Luehmann, \& Barab, 2003), or conducive to local adaptation. Embedding features that are explicitly educative for teachers who use the curriculum materials (Ball \& Cohen, 1996; Davis \& Krajcik, 2005) will help these materials speak to teachers rather than through them (Remillard, 2000), thus making the teacher-curriculum relationship more productive. For example, narrative vignettes associated with teachers' use of particular science curriculum materials can support preservice elementary teachers' developing pedagogical design capacity for inquiry-oriented science teaching (Dietz \& Davis, in press). These and other educative supports embedded within curriculum materials can help preservice teachers learn to employ principles of inquiry-oriented science teaching over time and across settings (Davis \& Krajcik, 2005). Better understanding the types of educative supports that can best support teachers at various stages along the teacher professional continuum is an important area for future research (Dietz \& Davis, in press; Schneider \& Krajcik, 2002).

\section{Implications for Identity-Based Educational Research}

These results also inform theoretical considerations of role identity and how to better capture and represent it through research. First, while our findings illustrate how identity and identity development within a given role can differ, attempts to define, articulate, and operationalize every conceivable task that constitutes a role present a challenge. On the one hand, the more robust a characterization of role identity, the more likely it is to capture those aspects of identity it is being used to explore. However, in doing so we also risk reducing complex science-teaching practices to categorized lists of specific behaviors relevant to the role in question. While accounting for both discrete actions and more complex activities is important for understanding how particular social activities operate and change (Engeström, 1987), identity is fundamentally concerned with how identities are acted out and negotiated between participants in complex social practices (Gee, 2000-2001; Goffman, 1959; Stets $\&$ Burke, 2000; Wenger, 1998). While any representation is inherently imperfect (Bourdieu, 1990), identity can be sufficiently operationalized by paying close attention to how teachers both represent it and put it to use within and across settings where science teaching and learning occur. 


\section{CONCLUSION}

This work adds to the body of literature concerned with the teacher-curriculum relationship (Remillard, 2005) and teachers' identity development (Mahlios, 2002). Curricular role identity helps further operationalize identity as a relevant factor in preservice teachers' learning and pedagogical design capacity. Future research should explore teachers' curricular role identity development over time and along the teacher professional continuum, as well as across grade levels and content domains, and work to further articulate underlying dimensions of curricular role identity for science teaching. Such work will help science teacher educators better understand how to support teachers in developing an identity for teaching within which the use of curriculum materials is a central component.

\section{APPENDIX A: SURVEY}

Please answer each of the following questions that refer to either you specifically or effective science teachers in general. Note that in this survey, the words terms instructional materials, curriculum materials, and lessons are used synonymously to refer to types of curriculum resources used in the science classroom (textbooks, worksheets, laboratory manuals, lesson plans, etc.).

Compared to all elementary teachers who teach science...

[Dimension 1: Curricular role identity for general use of science curriculum materials]

1. I am --- to evaluate curriculum materials for activities students are to carry out.

2. Effective science teachers are _-- to evaluate curriculum materials for activities students are to carry out.

3. I am _-- to evaluate curriculum materials for instructions and guidance they provide me as the teacher.

4. Effective science teachers are and guidance they provide the teacher.

5. I am _-- to adapt and modify curriculum materials than I am to use them as they're designed and written.

6. Effective science teachers are _-- to adapt and modify curriculum materials than they are to use them as they're designed and written.

7. I am _-- to evaluate curriculum materials based on how science concepts are presented and organized.

8. Effective science teachers are _-- to evaluate curriculum materials based on how science concepts are presented and organized.

[Dimension 2: Curricular role identity for scientific inquiry]

9. I am _-_ to use, adapt, or create science lessons that engage students in scientificallyoriented questions.

10. Effective science teachers are _-- to use, adapt, or create science lessons that engage students in scientifically-oriented questions.

11. I am -- to use, adapt, or create science lessons that encourage students to communicate and justify explanations.

12. Effective science teachers are --- to use, adapt, or create science lessons that encourage students to communicate and justify explanations.

13. I am -- to use, adapt, or create science lessons that encourage students to collect and analyze data and formulate explanations from evidence. 
14. Effective science teachers are --- to use, adapt, or create science lessons that encourage students to collect and analyze data and formulate explanations from evidence.

15. I am --- to help students make connections between science lessons and their own preexisting ideas about a topic.

16. Effective science teachers are _--- to help students make connections between science lessons and their own preexisting ideas about a topic.

[Dimension 3: Curricular role identity for curriculum materials' use in context]

17. I am _-- to evaluate curriculum materials for how well learning objectives are aligned with science standards.

18. Effective science teachers are --- to evaluate curriculum materials for how well learning objectives are aligned with science standards.

19. I am --- to use lessons that relate science concepts to students lives outside of school.

20. Effective science teachers are _-- to use lessons that relate science concepts to students lives outside of school.

21. I am -- to recognize that students may experience and react differently to science concepts based on their own values, beliefs, and culture.

22. Effective science teachers are _-- to recognize that students may experience and react differently to science concepts based on their own values, beliefs, and culture.

23. I am --_ to choose or modify science lessons based on what resources I have available.

24. Effective science teachers are _-- to choose or modify science lessons based on what resources they have available.

[Dimension 4: Curricular role identity for teacher learning from curriculum materials]

25. It is _-- that the way I teach a science lesson will change after I've taught it many times.

26. It is _-- that the way an effective science teacher teaches a science lesson will change after he or she has taught it many times.

27. I am --- to learn new instructional approaches from curriculum materials.

28. Effective science teachers are --- to learn new instructional approaches from curriculum materials.

29. I am --- to use curriculum materials to strengthen my content knowledge.

30. Effective science teachers often use curriculum materials to strengthen their content knowledge.

31. I am _-_ to reflect on my use of curriculum materials in order to improve my practice.

32. Effective science teachers are --- to reflect on their use of curriculum materials in order to improve their practice.

33. I am _-- to use curriculum materials to promote student learning, not my own learning.

34. Effective science teachers are --- to use curriculum materials to promote student learning, not their own learning. 


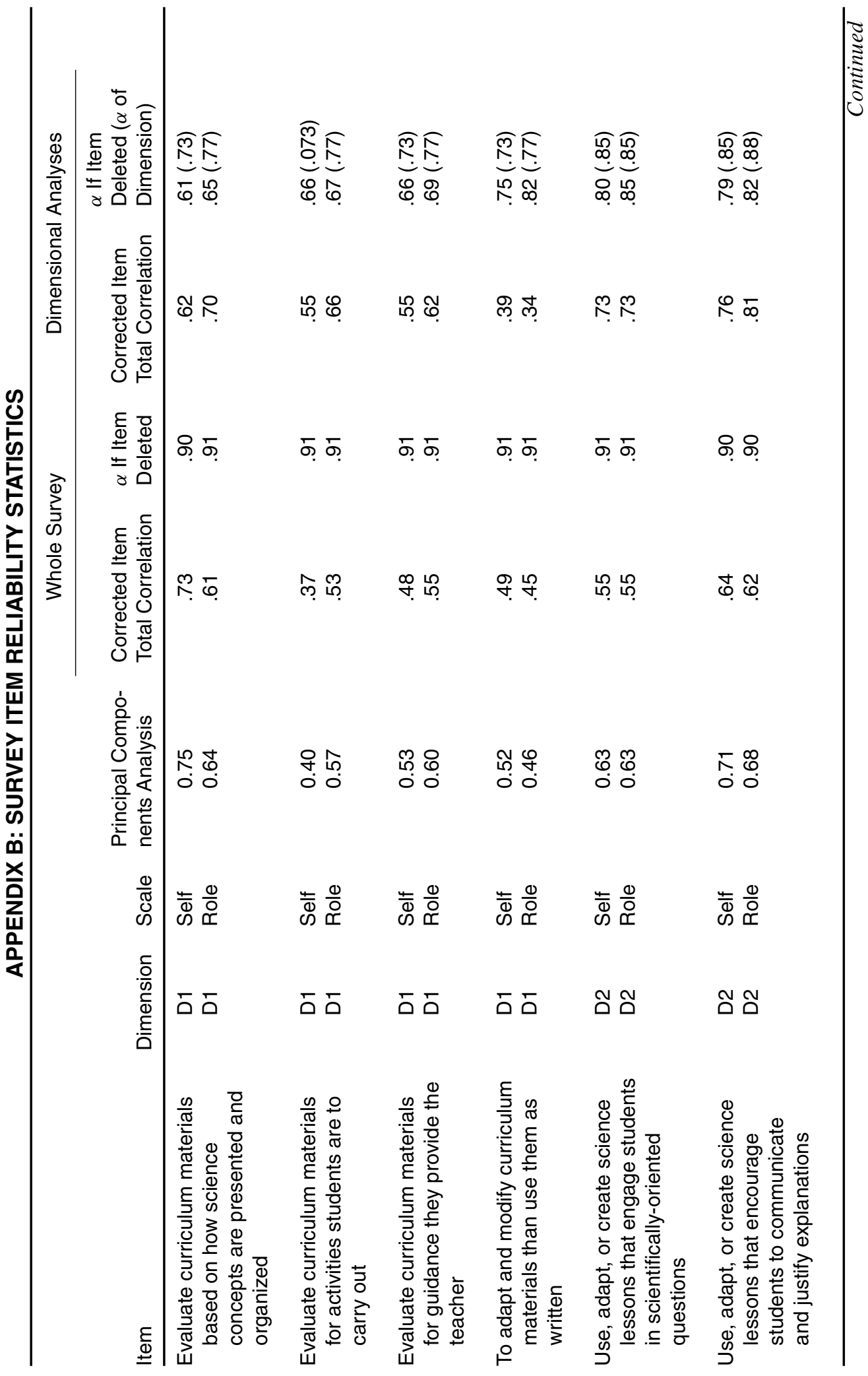




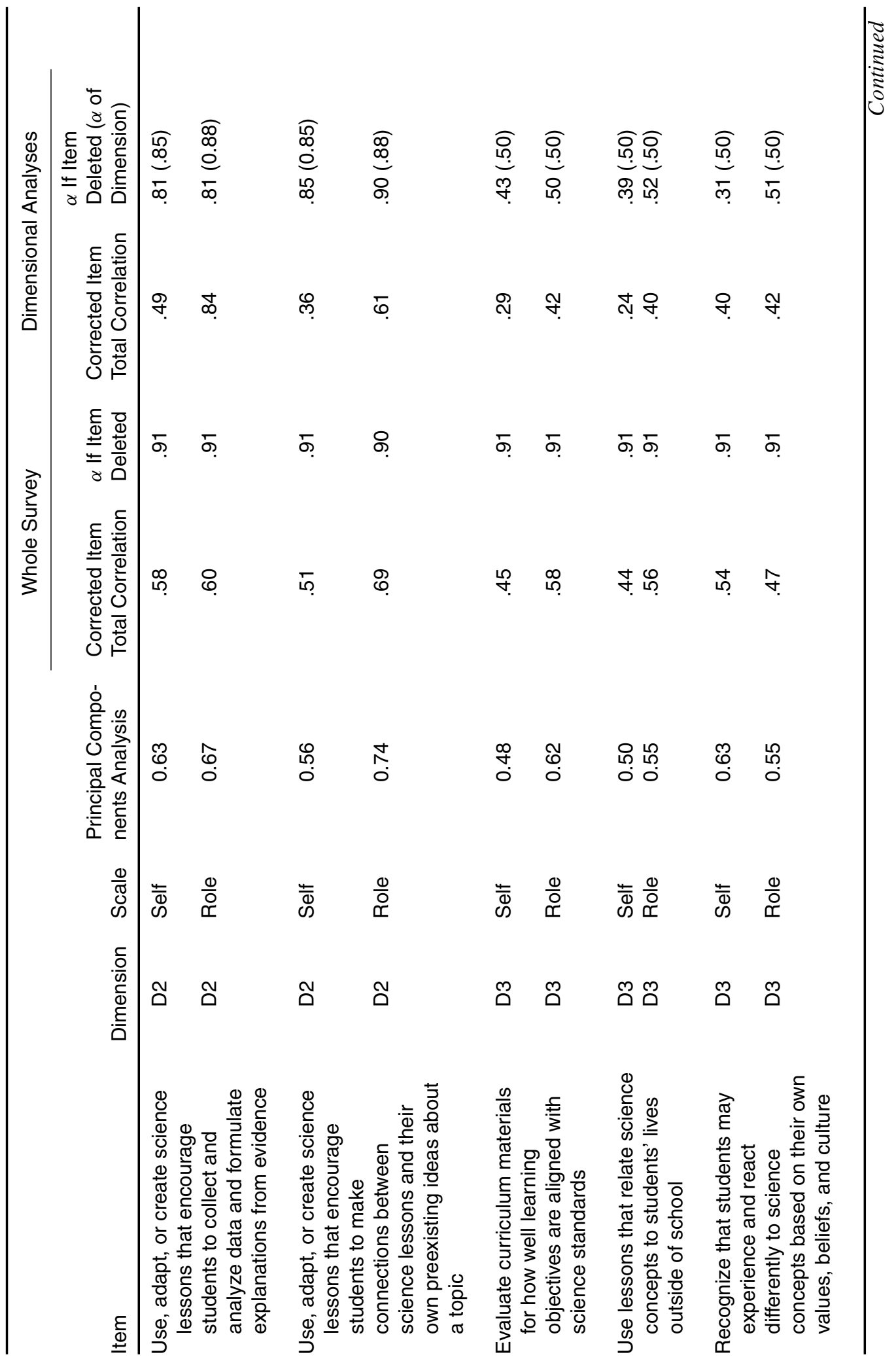




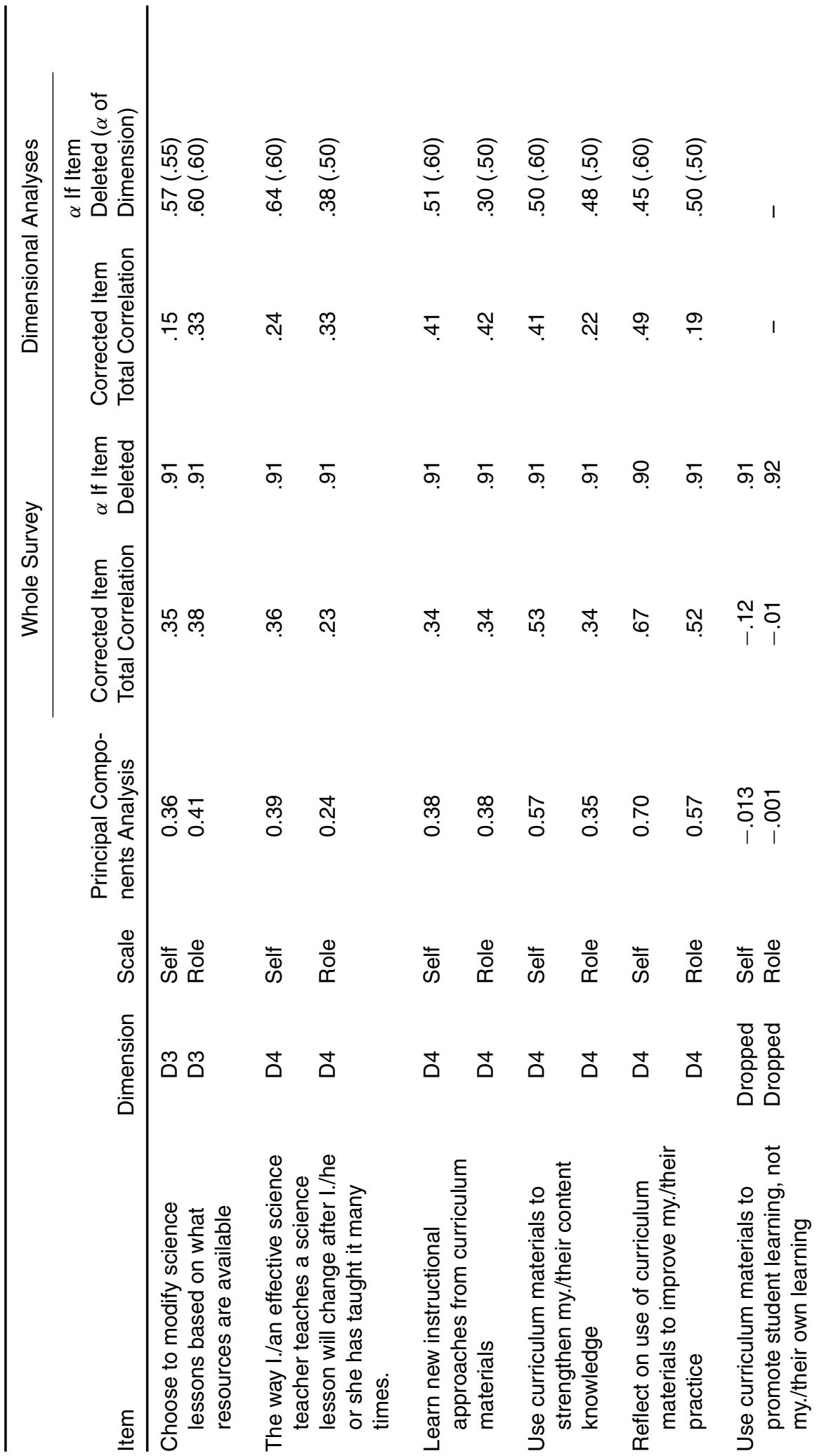




\section{APPENDIX C}

Intercorrelations Between the Four Individual Self Scales (Pearson Correlation, TwoTailed)

\begin{tabular}{lcccc}
\hline & D1 & D2 & D3 & D4 \\
\hline D1 & 1 & $.665\left(^{* *}\right)$ & $.656\left(^{* *}\right)$ & $.542\left(^{* *}\right)$ \\
D2 & 1 & $.743\left(^{* *}\right)$ & $.444\left(^{\star *}\right)$ \\
D3 & & 1 & $.524\left(^{\star *}\right)$ \\
D4 & & & 1 \\
\hline
\end{tabular}

${ }^{\star *}$ Correlation is significant at the 0.01 level (two-tailed).

Intercorrelations Between the Four Individual Role Scales (Pearson Correlation, TwoTailed)

\begin{tabular}{lcccc}
\hline & D1 & D2 & D3 & D4 \\
\hline D1 & 1 & $.567\left(^{\star \star}\right)$ & $.658\left(^{(*}\right)$ & $.499\left(^{\star \star}\right)$ \\
D2 & 1 & $.642\left(^{* \star}\right)$ & $.393\left(^{\star \star}\right)$ \\
D3 & & 1 & $.371\left(^{\star \star}\right)$ \\
D4 & & & 1 \\
\hline
\end{tabular}

${ }^{\star \star}$ Correlation is significant at the 0.01 level (two-tailed).

We appreciate the interest and cooperation of the preservice teachers who made the research reported here possible. We also thank Marc Mahlios, Carrie Beyer, Shawn Stevens, Julie Smithey, and Michele Nelson for their help in thinking about these issues and thoughtful comments on earlier versions of this paper.

\section{REFERENCES}

American Association for the Advancement of Science (1993). Benchmarks for science literacy, project 2061. New York: Oxford University Press.

Ball, D. L., \& Cohen, D. K. (1996). Reform by the book: What is—or might be-the role of curriculum materials in teacher learning and instructional reform? Educational Researcher, 25(9), 6-8, 14.

Ball, D. L., \& Lampert, M. (1999). Multiples of evidence, time, and perspective: Revisiting the study of teaching and learning. In E. C. Lagemann \& L. S. Shulman (Eds.), Issues in education research: Problems and possibilities (pp. 371-398). San Francisco: Jossey-Bass.

Barab, S. A., \& Luehmann, A. L. (2003). Building sustainable science curriculum: Acknowledging and accommodating local adaptation. Science Education, 87, 454-467.

Barab, S. A., \& Roth, W.-M. (2006). Curriculum-based ecosystems: Supporting knowing from an ecological perspective. Educational Researcher, 35(5), 3-13.

Berliner, D. C. (1986). In pursuit of the expert pedagogue. Educational Researcher, 15(7), 5-13.

Beyer, C. J., Delgado, C., Davis, E. A., \& Krajcik, J. Investigating high school biology texts as educative curriculum materials: Curriculum review process. Manuscript submitted for publication.

Boaler, J., \& Greeno, J. (2000). Identity, agency and knowing in mathematics worlds. In J. Boaler (Ed.), Multiple perspectives on mathematics teaching and learning (pp. 171-200). Westport, CT: Ablex.

Bourdieu, P. (1990). The logic of practice. Stanford, CA: Stanford University Press.

Bransford, J. D., Brown, A. L., \& Cocking, R. R. (Eds.). (2000). How people learn: Brain, mind, experience, and school. Washington, DC: National Academy Press. 
Brown, M. (2002). Teaching by design: Understanding the intersection between teacher practice and the design of curricular innovations. Doctoral Dissertation, Northwestern University.

Brown, M. (in press). Toward a theory of curriculum design and use: Understanding the teacher-tool relationship. In B. Herbel-Eisenman, J. Remillard, \& G. Lloyd (Eds.), Teachers' use of mathematics curriculum materials: Research perspectives on the relationship between teachers and curriculum.

Brown, M., \& Edelson, D. (2003). Teaching as design: Can we better understand the ways in which teachers use materials so we can better design materials to support their changes in practice? Evanston, IL: The Center for Learning Technologies in Urban Schools.

Bullough, R. V., Jr., Knowles, J. G., \& Crow, N. A. (1992). Emerging as a teacher. New York: Routledge.

Burke, P. J., \& Reitzes, D. C. (1981). The link between identity and role performance. Social Psychology Quarterly, 44(2), 83-92.

Clift, R. T., \& Brady, P. (2005). Research on methods courses and field experiences. In M. Cochran-Smith \& K. Zeichner (Eds.), Studying teacher education: The report of the AERA panel on research and teacher education (pp. 309-424). Mahwah, NJ: Erlbaum.

Collier, P. (2001). A differentiated model of role identity acquisition. Symbolic Interaction, 24(2), 217-235

Collopy, R. (2003). Curriculum materials as a professional development tool: How a mathematics textbook affected two teachers' learning. The Elementary School Journal, 103(3), 287-311.

Crawford, B. (1999). Is it realistic to expect a preservice teacher to create an inquiry-based classroom? Journal of Science Teacher Education, 10(3), 175-194.

Davis, E. A. (2006). Preservice elementary teachers' critique of instructional materials for science. Science Education, 90(2), 348-375.

Davis, E. A., \& Krajcik, J. (2005). Designing educative curriculum materials to promote teacher learning. Educational Researcher, 34(3), 3-14.

Davis, E. A., Petish, D., \& Smithey, J. (2006). Challenges new science teachers face. Review of Educational Research, 76(4), 607-651.

Davis, E. A., Smithey, J., \& Petish, D. (2004). Designing an online learning environment for new elementary science teachers: Supports for learning to teach. In Y. B. Kafai, W. A. Sandoval, N. Enyedy, A. S. Nixon, $\&$ F. Herrera (Eds.), Proceedings of the 6th International Conference of the Learning Sciences, ICLS2004. Mahwah, NJ: Lawrence Erlbaum Associates.

Dietz, C. M., \& Davis, E. A. (in press). Preservice elementary teachers' reflection on narrative images of inquiry. Journal of Science Teacher Education.

Drake, C., Spillane, J. P., \& Hufferd-Ackles, K. (2001). Storied identities: Teacher learning and subject-matter context. Journal of Curriculum Studies, 33(1), 1-23.

Eick, C., Ware, F. N., \& Williams, P. G. (2003). Coteaching in a science methods course: A situated model of becoming a teacher. Journal of Teacher Education, 54(1), 74-85.

Engeström, Y. (1987). Learning by expanding: An activity-theoretical approach to developmental research. Helsinki, Finland: Orienta-Konsultit.

Enyedy, N., \& Goldberg, J. (2004). Inquiry in interaction: How local adaptations of curricula shape classroom communities. Journal of Research in Science Teaching, 41(9), 905-935.

Enyedy, N., Goldberg, J., \& Welsh, K. M. (2006). Complex dilemmas of identity and practice. Science Education, 90, 68-93.

Feiman-Nemser, S. (2001). From preparation to practice: Designing a continuum to strengthen and sustain teaching. Teachers College Record, 103(6), 1013-1055.

Fishman, B., Marx, R., Best, S., \& Tal, R. (2003). Linking teacher and student learning to improve professional development in systemic reform. Teaching and Teacher Education, 19(6), 643-658.

Fishman, B. J., \& Krajcik, J. (2003). What does it mean to create sustainable science curriculum innovations? A commentary. Science Education, 87, 564-573.

Forbes, C. T., \& Davis, E. A. (in press). Exploring preservice elementary teachers' critique and adaptation of science curriculum materials in respect to socioscientific issues. Science \& Education.

Forbes, C. T., \& Davis, E. A. Beginning elementary teachers' learning through the use of science curriculum materials: A longitudinal study. Manuscript submitted for publication.

Gee, J. P. (2000-2001). Identity as an analytic lens for research in education. Review of Research in Education, $25,99-125$.

Goffman, E. (1959). The presentation of self in everyday life. New York: Anchor./Doubleday.

Graue, M. E. (2005). Theorizing \& describing preservice teachers' images of families and schooling. Teachers College Record, 107(1), 157-185.

Helms, J. V. (1998). Science-and me: Subject matter and identity in secondary school science teachers. Journal of Research in Science Teaching, 35(7), 811-834

Hiebert, J., Gallimore, R., \& Stigler, J. W. (2002). A knowledge base for the teaching profession: What would it look like and how can we get one? Educational Researcher, 31(5), 3-15. 
Holland, D., Lachicotte, Jr. W., Skinner, D., \& Cain, C. (1998). Identity and agency in cultural worlds. Cambridge, MA: Harvard University Press.

Hutchins, E. (1995). Cognition in the wild. Cambridge, MA: MIT Press.

Kauffman, D., Johnson, S. M., Kardos, S. M., Liu, E., \& Peske, H. (2002). “Lost at sea”: New teachers' experiences with curriculum and assessment. Teachers College Record, 104(2), 273-300.

Kesidou, S., \& Roseman, J. (2002). How well do middle school science programs measure up? Findings from project 2061's curriculum review. Journal of Research in Science Teaching, 39(6), 522-549.

Kozoll, R. H., \& Osborne, M. D. (2003). Finding meaning in science: Lifeworld, identity, and self. Science Education, 88, 157-181.

Lave, J., \& Wenger, E. (1991). Situated learning: Legitimate peripheral participation. Cambridge, England: Cambridge University Press.

Lemke, J. L. (2000). Across the scales of time: Artifacts, activities, and meanings in ecosocial systems. Mind, Culture, and Activity, 7(4), 273-290.

Lemke, J. L. (2001). Articulating communities: Sociocultural perspectives on science education. Journal of Research in Science Teaching, 38(3), 296-316.

Lloyd, G. M. (1999). Two teachers' conception of a reform-oriented curriculum: implications for mathematics teacher development. Journal of Mathematics Teacher Education, 2(3), 227-252.

Lortie, D. (1975). School teacher: A sociological study. Chicago: University of Chicago Press.

Mahlios, M. (2002). Teacher role formation. Action in Teacher Education, 24(1), 9-21.

Marx, R., \& Harris, C. (2006). No child left behind and science education: Opportunities, challenges, and risks. The Elementary School Journal, 106(5), 467-477.

Miles, M. B., \& Huberman, A. M. (1994). Qualitative data analysis. Newbury Park, CA: Sage.

National Research Council (1996). National Science Education Standards. Washington, DC: National Research Council.

National Research Council (2000). Inquiry and the National Science Education Standards: A guide for teaching and learning. Washington, DC: National Academy Press.

Patton, M. Q. (2001). Qualitative research and evaluation methods. Thousand Oaks, CA: Sage.

Pintó, R. (2004). Introducing curriculum innovations in science: Identifying teachers' transformations and the design of related teacher education. Science Education, 89, 1-12.

Putnam, R. T., \& Borko, H. (2000). What do new views of knowledge and thinking have to say about research on teacher learning? Educational Researcher, 29(1), 4-15.

Remillard, J. T. (1999). Curriculum materials in mathematics education reform: A framework for examining teachers' curriculum development. Curriculum Inquiry, 29(3), 315-342.

Remillard, J. T. (2000). Can curriculum materials support teachers' learning? Two fourth-grade teachers' use of a new mathematics text. The Elementary School Journal, 100(4), 331-350.

Remillard, J. T. (2005). Examining key concepts in research on teachers' use of mathematics curricula. Review of Educational Research, 75(2), 211-246.

Remillard, J. T., \& Bryans, M.B. (2004). Teachers' orientations toward mathematics curriculum materials: Implications for teacher learning. Journal of Research in Mathematics Education, 35(5), 352-388.

Reveles, J. M., Kelly, G. J., \& Durán, R. P. (2007). A sociocultural perspective on mediated activity in third grade science. Cultural Studies of Science Education, 2(1), 467-495.

Richardson, V. (1996). The role of attitudes and beliefs in learning to teach. In J. Sikula, T. Buttery, \& E. Guyton (Eds.), Handbook of research on teacher education (pp. 102-119). New York: Macmillan.

Roehrig, G. H., \& Kruse, R. A. (2005). The role of teachers' beliefs and knowledge in the adoption of a reformbased curriculum. School Science and Mathematics, 105(8), 412-422.

Roth, W.-M. (1998). Teaching and learning as everyday activity. In B. J. Fraser \& K. G. Tobin (Eds.), International handbook of science education (pp. 169-181). Dordrecht, The Netherlands: Kluwer.

Schneider, R., \& Krajcik, J. (2002). Supporting science teacher learning: The role of educative curriculum materials. Journal of Science Teacher Education, 13(3), 221-245.

Schneider, R. M., Krajcik, J., \& Blumenfeld, P. (2005). Enacting reform-based science materials: The range of teacher enactments in reform classrooms. Journal of Research in Science Teaching, 42(3), 283-312.

Schwarz, C., Gunckel, K., Smith, E., Covitt, B., Enfield, M., Bae, M., \& Tsurusaki, B. (in press). Helping elementary pre-service teachers learn to use science curriculum materials for effective science teaching. Science Education.

Schwartz, D., Lin, X., Brophy, S., \& Bransford, J. D. (1999). Toward the development of flexibly adaptive instructional design. In C. Reigeluth (Ed.), Instructional-design theories and models: A new paradigm of instructional theory (pp. 183-214). Mahwah, NJ: Erlbaum.

Sfard, A., \& Prusak, A. (2005). Telling identities: In search of an analytic tool for investigating learning as a culturally shaped activity. Educational Researcher, 34(4), 14-22.

Shulman, L. (1986). Those who understand: Knowledge growth in teaching. Educational Researcher, 15(2), 4-14. 
Smithey, J., \& Davis, E. A. (2004). Preservice elementary science teachers' identity development: Identifying with particular images of inquiry. In Y. B. Kafai, W. A. Sandoval, N. Enyedy, A. S. Nixon, \& F. Herrera (Eds.), Proceedings of the 6th International Conference of the Learning Sciences, ICLS2004. Mahwah, NJ: Erlbaum.

Spillane, J. P. (2000). A fifth-grade teachers' reconstruction of mathematics and literacy learning: Exploring interactions among identity, learning, and subject matter. The Elementary School Journal, 100(4), 307-330.

Squire, K. D., MaKinster, J. G., Barnett, M., Luehmann, A. L., \& Barab, S. L. (2003). Designed curriculum and local culture: Acknowledging the primacy of classroom culture. Science Education, 87, 468-489.

Stets, J. E., \& Burke, P. J. (2000). Identity theory and social identity theory. Social Psychology Quarterly, 63(3), $224-237$.

U.S. Department of Education, National Center for Education Statistics (NCES). (2003). Digest of education statistics, 2003. Retrieved July 1, 2005, from http:.//nces.ed.gov/programs/digest/2003menu_tables.asp

Valencia, S., Place, N., Martin, S., \& Grossman, P. (2006). Curriculum materials for elementary reading: Shackles and scaffolds for four beginning teachers. The Elementary School Journal, 107(1), 93-120.

Wenger, E. (1998). Communities of practice: Learning, meaning, and identity. New York: Cambridge University Press.

Windschitl, M. (2003). Inquiry projects in science teacher education: What can investigative experiences reveal about teacher thinking and eventual classroom practice? Science Education, 87(1), 112-143.

Zeichner, K. M., \& Conklin, H. G. (2005). Teacher education programs. In M. Cochran-Smith \& K. Zeichner (Eds), Studying teacher education: The report of the AERA Panel on Research and Teacher Education (pp. 645-736). Mahwah, NJ: Erlbaum.

Zeichner, K. M., \& Gore, J. (1990). Teacher socialization. In W. Robert Houston (Ed.), Handbook of research on teacher education (pp. 329-348). New York: Macmillan. 